\title{
Communication in Training Future EFL Teachers: Simulation and Roleplay in the English Classroom
}

\author{
Karina Muratovna Amirkhanova ${ }^{1} \&$ Natalia Nikolaevna Bobyreva ${ }^{1}$ \\ ${ }^{1}$ Department of European Languages and Cultures, Institute of International Relations, Kazan (Volga Region) Federal \\ University, Russia \\ Correspondence: Karina Muratovna Amirkhanova, Department of European Languages and Cultures, Institute of \\ International Relations, Kazan (Volga Region) Federal University, Russia.
}

Received: September 1, 2020

Accepted: October 21, 2020

Online Published: October 31, 2020

doi:10.5430/ijhe.v9n8p7

URL: https://doi.org/10.5430/ijhe.v9n8p7

\begin{abstract}
The issue under investigation is topical and significant. Being a communicative language acquisition method, simulation and roleplays develop future teachers' language competencies and pedagogical competence, playing a unique role in forming teacher-student, teacher-parent communication patterns. The article aims at studying the place simulation/roleplay have in this process and its specific features. The authors describe how roleplays and simulations are introduced into the English classroom, examples of supplying study books with roleplay tasks. The methods applied to explore the problem were observation and questionnaire administered to the students at the end of the course. Their analysis has permitted the authors to arrive at several conclusions. The most remarkable conclusion is that introducing simulation/roleplay into the study process significantly influences students' communication skills and academic performance, forming their pedagogic competences and communication patterns. Furthermore, the findings revealed that simulation/roleplay in training foreign language teachers should be well-planned and organized; the author gives some advice concerning it. The study results could be highly substantial for teachers of universities preparing future foreign language teachers.
\end{abstract}

Keywords: communication, role play, student, the teacher of the XXI century, university education

\section{Introduction}

The Communicative approach refers to language teaching theories, which emphasize that the goal of language learning is communicative competence, which refers to where and to whom in a speech community to use grammar structures and the new vocabulary. Researchers use the term "communicative activities" to refer to techniques which are employed in the communicative method in language teaching, describing such characteristics if it as their being purposeful and interactive, the use of authentic materials, and there being based on the information gap principle (Yee, 1990). The essence of this approach is to communicate with another person in the classroom and society in the long term.

Being a precious EFL teaching method, simulation/roleplaying provides good interaction between participants, acquisition of the language aspects, thus, developing communication language ability, enhancing students' motivation.

There exist different views on the simulation. As Jones wrote, in simulation, participants have (functional) roles, duties, and sufficient key information about the problem to carry out these duties without play-acting or inventing key facts. He found the simulation different from the role play as in a roleplay, participants are acting their part, and there is minimal background information (Jones, 1980). According to M. Gredler, unlike games, simulations are evolving case studies of a particular social or physical reality (Gredler, 1992). Both can be free-form and rule-driven, thus generating different types of interactive learning environments. Ladousse considers simulations to be complicated, lengthy, and relatively inflexible events that include Roleplay. On the other hand, role play, being very flexible, can be quite simple in terms of organizing. Role-play is included in the simulation but is not by any means confined to them (Ladousse, 2004). According to Scarcella \& Crookall (1997), simulation/role play facilitates second language acquisition. Students are engaged in positive communication, developing long-term motivation, developing their problem-solving skills, and critical thinking.

Simulation/roleplay is considered within the communication language acquisition framework and is to be studied as 
one common approach to language acquisition. Researchers state that simulation/role play in EFL class optimizes the possibilities for language acquisition.

Moreover, roleplays/simulations based on teaching situations are essential for future EFL teacher educators. They provide opportunities for prospective teachers to gain investigative skills and methodology for making decisions about what to teach and how and how to communicate, organize, and motivate their students. The pedagogic knowledge - to help learners of all ages and learning styles acquire language knowledge - comes as an essential competence as well.

A worldwide issue is the preparation of EFL teachers of the XXI century who could overcome the problems of first years at school teaching and their being able to put the theory into practice. A large number of studies reveal various factors affecting teachers' performance. Among these factors are: the entry-level teachers have to struggle mainly with various aspects of classroom management and discipline, with motivating students to learn contradictions between expectations and reality, being uninformative about the social and political context of schools (Herbert \& Worthy, 2001); getting disillusioned (Moir,1990; Mathew \& Alidmat, 2013). Researchers enumerate among the challenges beginning teachers face: heavy workloads, students' and parents' demands, students' discipline, and undefined role expectations (Townsend \& Bates, 2007). A conclusion can be drawn that, generally, those problems arise from too little practical experience while studying at higher education institutions.

Korthagen (1990) writes that "realistic teacher education starts from student teachers' experiences rather from the objective theories on learning and teaching". The university has the opportunity to smooth the transition of future EFL teachers into schools by equipping them with skills to manage a so-called "pedagogical communication," which includes solving educational, developmental, and pedagogical tasks. University education of future EFL teachers should include simulations/roleplays in English classrooms as well (Muhammad, 2020: Abdullina et al, 2019).

\section{Methods}

In Kazan Federal University (Institute of International Relations) future EFL teachers' curriculum includes Linguistics, Language Learning Theory Courses, Language teaching methodology, Pedagogy, Psychology, Classroom-based Research, and others.

The practical course of English is taught to all linguistics students, but this course for those who chose English teaching as a profession includes a teaching practice component.

As such courses as Psychology, Pedagogy, and Language Teaching Methodology are introduced in the third year of studies, at the Practical Course of English class, the third-year students are supposed to prepare "lesson fragments" (mini-lessons) where they the part of "teachers" while the group has roles of "pupils". The functions of the "teacher" are the following: prepare a word (from Active vocabulary of the corresponding Unit in the Coursebook), introduce a new word with all its meanings in different contexts, providing examples from dictionaries, prepare exercises to drill its use, prepare a task to assess the level of this word's understanding. Students preparing the mini-lesson are to follow instructions given by their English language teacher. The mini-lesson should meet all the necessary requirements: it should have time limits, be well-structured from the point of view of teaching methods and rules applied to work with vocabulary. After the lesson, the teacher and student discuss the mini-lesson form the point of view of its content; structure; aims and results; interaction with other "pupils" of the "class", atmosphere (friendly/positive, level of anxiety, and possible reasons for it); mistakes made by the "pupils" and the "teacher" and possible ways to avoid them.

Professional development is considered to be an ongoing process of critical inquiry (Loughran \& Hamilton, 2007). EFL teachers are expected to engage in practice and continually ask how to improve their practice. Therefore students should acquire reflection skills throughout their studies at the university. The questions they ask themselves and the answers they formulate become the foundation for their continuing approach to practice. This is the reason why reflection on the "mini-lessons" is included in the activity as a constituent part. Besides, after the "mini-lesson" all students who had acted as "pupils" also take an active part in discussing the positive and negative points, for instance, they can make comments on what problems they had had in understanding, making examples, pronouncing; they can comment on the class atmosphere, way of the "teacher's" behavior. This is a useful way for future teachers to look at the process with pupils' eyes and plan their own behavior according to it (Octaberlina \& Muslimin, 2020).

Simulation and Roleplay also are introduced into classroom activities of the Practical course of English. Instructional material includes the Speakout coursebook (Eales \& Oakes, 2015) and Practical Course of English by V.D.Arakin (Arakin, 2005) which are equipping future English teachers with knowledge of English. The coursebooks' learning material is divided into units, each including active vocabulary and grammar material, speaking, and writing sections. 
In the coursebook Practical Course of English by V.D.Arakin all the units contain a roleplay task, such as the roleplay "Formal versus Informal Teaching" in Unit 3 (topic English Schooling), but not all of them deal with pedagogy; therefore, a teacher himself makes up and offers the students to take part in it. For instance, in the first Unit (Changing Patterns of Leisure), the task could be: one person is a school headmaster, five are schoolteachers, others play the roles of parents, each having their own opinion and views on the way the children could spend their vacation proposing walking tours/hiking/river trip etc. The aim is to agree on the vacation type. Cards with roles are distributed to students, and they have 5 minutes to study the background information and prepare their arguments. The Roleplay itself has a time limit, and the teacher's duty is to keep it under control. It is important to mention that in this very Roleplay, students can play parts of schoolchildren's parents, which could be useful for future teachers who are supposed to communicate not only with pupils but also with their parents. The second Unit of the above-mentioned coursebook, Man and the Movies, can also be supplied with a roleplay; for instance, students can be offered the following task: they are to perform parts of schoolteachers, each having their own background and teaching experience, and discuss a movie they could bring their pupils to watch, each bringing arguments for the movie he/has to propose, for example, wartime epic, comedy, drama, science fiction, and agree on of them.

It is useful to make students take part in roleplays where they could put themselves on their pupils' places; for example, in Unit 5 (Bringing Up Children), they could act out a situation "The Meeting of the Teachers' Council" where schoolchildren and teaching staff discuss a girl-pupil who came to school with her hair dyed, and they decide whether the schoolchildren can attend school with their hair dyed. As in all other roleplays, students get cards with all details concerning their roles, where their characters and their views are described, and they have to come to a certain conclusion.

The Speakout student's book does not contain any methodologically-oriented roleplays as it is a general English coursebook, but it is up to a teacher to provide an exceptional roleplay; for example, Unit 9, dealing with the Arts topic, can be supplied with the following Roleplay: school teachers, headmaster and parents council, decide what museums to visit during summer vacation, some of them insist on visiting classical Picture Gallery, some - on visiting Modern Arts and Sculpture museum (all information is written on their cards). For Unit 1 of Speakout (topic Personalities), a roleplay could contain a parents-teachers discussion about whether or not to include in teaching practice tests to measure pupils' abilities and how it could influence the schoolchildren.

\section{Results and Discussion}

Seventy-four third-course students, 72 females, and two males participated in the study. All of them took part in roleplays organized and conducted according to the above-presented principles and prepared mini-lessons. At the end of the academic year, we used an anonymous survey that contained a question based on a 5-point Likert test where items ranged from 1 (Strongly disagree) to 5 (Strongly agree). Students answered the question: 1 . Do you find the roleplays/simulations useful? If yes, how would you assess its use? All students answered "yes" to this question, and the result was rated 4.8 , which shows a high level of satisfaction. To learn more about their attitudes towards the simulation/roleplay, they were asked to answer two more questions: 2. In what ways did you benefit from the simulation/roleplays? And 3. What drawbacks did you find in this activity? The possible variants of answers could be unlimited. The communicative approach refers to language teaching theories, which emphasize that the goal of language learning is communicative competence, which refers to where and to whom in a speech community to use grammar structures and the new vocabulary. Researchers use the term "communicative activities" to refer to techniques which are employed in the communicative method in language teaching, describing such characteristics if it as their being purposeful and interactive, the use of authentic materials, and their being based on the information gap principle (Jones, 1980). The essence of this approach is to communicate with another person in the classroom and society in the long term.

The answers of the students were: - useful for my future teaching activities (including - trying hand at teaching) (72); using classroom expressions (69); - useful for learning/remembering the vocabulary of the corresponding Unit (67); training spontaneous speech (56); - better understanding the way study material should be explained and drilled (43); developing communicative skills (41); - mastering the language (38); - better understanding children's psychology (37); - seeing possible difficulties in classroom contexts (35); - becoming more confident in speaking the language overcoming a language barrier/shyness/anxiety/fear/ of speaking the language (34); - finding ways out in difficult pedagogical situations (21); - motivating for starting teaching career (15); - hearing other people's mistakes and understanding your own mistakes (15); - developing skills of speaking in public (13); - development of creative thinking skills (3); - possibility to see one's own weak points in English. 
To the third question - "What drawbacks/difficulties did you find in these activities?" Forty-five students answered "No/nothing", the other 29 students' answers were: - difficult to get prepared (9); - fear to fail (7); - time limits (5); lack of vocabulary to express all ideas (4); - for shy people there is a fear to speak in public (2); - lack of sincere interest in the material (2); - as there are no real schoolchildren, it differs from a real situation and (1).

It is significant to note that among the benefits, the students have enumerated many variants, but drawbacks/difficulties, if mentioned any, were mainly mentioned only one by almost every student.

As Senior writes, the necessity for a teacher to pay attention to their students' learning and social needs enables language teachers to behave in flexible ways that promote learning (Senior, 2006). One of the tools to engage EFL students in language studies is the use of simulations/roleplays. Moreover, a university teacher should be concentrating on searching ways of building an educational process based on communicative, person-centered, and interactive approaches, increasing organizational changeability of the educational environment (Abrosimova, 2019).

On the other hand, researchers point out a problem of beginning EFL teachers with having and developing competence in putting theory into practice (Korthagen \& Kessels 1990). Graduates mention their need to be aware of different techniques and activities to adapt materials and manage classes. To prevent them from having the problem, simulation/roleplay should be included in their foreign language class in university.

Researchers focus on searching for ways to intensify the process of teaching a foreign language in university, pointing out the gaming and Roleplay as one of its possible means (Plachova, 2019). We agree with Ladousse (2004) that to be an effective tool of the educational process and provide positive outcomes, roleplays: - must be carefully planned; should have a strong link to the material under study; - all roles and situations should be flexible to get adapted to the number of students taking part in it; - role card should be concise and contain only essentials containing vocabulary and structures students are already familiar with; - after delivering the role cards, it is necessary to make sure all students understand the situation; - time limit should be set; - teacher's role is to keep the situation under control; - the roleplay situation itself shouldn't be overloaded with emotions; otherwise, it could come to chaos.

As there is a widespread view that theory is constituted through reflection and it is necessary to engage subjectivity and reflexivity in teaching (Kondrateva et al., 2018), students are supposed to reflect on their development in Roleplay, which is considerable evidence of their progress. The student' reflective writing should refer to the development of both their subject knowledge and pedagogical knowledge.

We have concluded that the use of roleplays/simulations in the classroom fosters communication between learners and provides opportunities to use the target language in various "make-believe" situations, but it also has effect in terms of social interaction and cultural awareness.

\section{Summary}

The importance of developing professional competences in future EFL teachers in English Language classrooms is obvious.

The article studies the place simulation/role play can have in the English university classroom in training future EFL teachers. The experiment results showed that alongside such traditional subjects included in future teachers' curriculum as Psychology, Pedagogy, and Language Teaching Methodology, English classes could also equip future teachers with the necessary pedagogic competencies, especially the necessary communication skills sphere. The article provides examples of supplying English language coursebooks with roleplays to foster communication with teachers/pupils/parents.

\section{Conclusions}

The study's focus was to demonstrate the power of Roleplay used in EFL classrooms in fostering communication to prepare future EFL teachers. Roleplays and simulations are a useful tool to develop not only future teacher's language competences (his expertise), but also such competences as possession of methods of professional language teacher's activities, deep understanding of foreign languages teaching and learning processes, general pedagogical knowledge (the organization of the classroom, motivating and retaining students' attention, taking into account principles of classroom management and organization, comprehension and interpretation of the school classroom, after-class reflection). Moreover, this kind of roleplays contributes to developing competencies related to such social activities as skills of social interaction and social responsibilities (social competencies required to succeed in dealing with schoolchildren, their parents, teaching staff). 


\section{Acknowledgements}

The work is performed according to the Russian Government Program of Competitive Growth of Kazan Federal University.

\section{References}

Abrosimova, G., Kondrateva, I., Voronina, E., \& Plotnikova, N. (2019). Blended Learning In University Education. Humanities \& Social Sciences Reviews, 7(6), 06-10. https://doi.org/10.18510/hssr.2019.762

Arakin, V. D. (2005). Prakticheskii kurs angliiskogo yazyka: 2 kurs: Ucheb. dlya studentov vuzov / Pod red. V.D. Arakina. - 7-e izd., dop. i ispravl. - M.: Gumanit. izd.tsentr VLADOS.

Eales, F., \& Oakes, S. (2015). Speakout. Upper-Intermediate. Students' Book. 2nd Ed. - Pearson Education Limited.

Gredler, M. E. (1992). Designing and evaluating games and simulations. London: Kogan Pag.

Herbert, E., \& Worthy, T. (2001). Does the first year of teaching have to be a bad one? A case study of success. Teaching and Teacher Education, 17, 897-911. http://doi.org/10.1016/S0742-051X(01)00039-7

Sam, Wan Yee. (1990). Drama in Teaching English as a Second Language - A Communicative Approach. The Teacher. Retrieved from https://journals.melta.org.my/index.php/tet/article/view/479

Jones, K. (1980). Simulations: A Handbook for Teachers. London: Kegan Paul Ltd.A. Petrov, "General theory of relativity", Annalen der Physik, 49(7), 769-822, 1916.

Kondrateva, I., Sabirova, D., \& Plotnikova, N. (2018). Subjectivity functions in the reflexive and intercultural process of linguistic development. Cypriot Journal of Educational Sciences, 13(4), 529-536. https://doi.org/10.18844/cjes.v13i4.3858

Korthagen, F. A. J., \& Kessels, J. P. A. M. (1990). Linking Theory and Practice: Changing the Pedagogy of Teacher Education. Educational Researcher, 28(4), 4-17. https://doi.org/10.3102/0013189X028004004

Ladousse, G. P. (2004). Role Play. Oxford University Press.

Loughran, J., \& Hamilton, M. L., LaBoskey, V. K., \& Russell, T. (2007). International Handbook of Self-Study and Teacher Education Practices, Part 1. Springer.

Mathew, N. G., \& Alidmat A. O. (2013). A Study on the Usefulness of Audio-Visual Aids in EFL Classroom: Implications for Effective Instruction. International Journal of Higher Education. 2(2), 4-9. https://doi.org/10.5430/ijhe.v2n2p86

Mendoza, Velazco, D. J., \& Rivero Padrón, Y. (2019). Teaching Resource for the Teaching of Geometry: Circular Trigonometric Geoplane. International Electronic Journal of Mathematics Education, 14(1), 3-13. https://doi.org/10.12973/iejme/3936

Moir, E. (1990). Phases of first-year teaching. New Teacher News, 2(2), 6-7.

Muhammad, M. (2020). Promoting Students' Autonomy through Online Learning Media in EFL Class. International Journal of Higher Education, 9(4), 3-11. https://doi.org/10.5430/ijhe.v9n4p320

Murray, T. V. (1997). Problema "svoego" $i$ "chuzhogo" v context problem tsennosti cheloveka// "Svoe" $i$ "chuzhoe" $v$ culture narodov Evropeiskogo Severa - Pertozavodsk, 17-20.

Narkevich, L. V., \& Narkevich, E. A. (2018). Financial condition analysis in the crisis management system. Russian Economic Bulletin, 1(4), 10-24.

Octaberlina, L. R., Muslimin, A. I. (2020). EFL Students Perspective towards Online Learning Barriers and Alternatives Using Moodle/Google Classroom during COVID-19 Pandemic. International Journal of Higher Education, 9(6), 13. https://doi.org/10.5430/ijhe.v9n6p1

Plachova, E. A., Kharapudko, E. N., \& Nurmieva R. R. (2019). Game techniques as a method of the educational process intensification in teaching a foreign language. Humanities and Social Sciences Reviews, 6, 38-44. https://doi.org/10.18510/hssr.2019.769

Scarcella, R., \& Crookall, D. (1990). Simulation/gaming and language acquisition. In D. Crookall \& R. L. Oxford (Eds.), Simulation, gaming, and language learning (pp. 223-230). New York: Newbury House, 1990.

Selomo, M. R., \& Govender, K. K. (2016). Procurement and Supply Chain Management in Government Institutions: A 
Case Study of Select Departments in the Limpopo Province, SouthAfrica. https://doi.org/10.20897/lectito.201637

Senior, R. (2006). The Experience of Language Teaching. Cambridge University Press. https://doi.org/10.1017/CBO9781139523912

Sergeeva, M. G., \& Trubakova D. I. (2016). Teacher's Reflection Formation as a Factor of Effectiveness Children's Social Intelligence Forming. Modern Scientist, 7, 62-64.

Townsend, T., \& Bates, R. (2007). Handbook of Teacher Education: Globalization, Standards and Professionalism in Times of Change. 1st ed. Springer. https://doi.org/10.1007/1-4020-4773-8

Tsahaeva A. A., Aminov U. K., \& Aminova, D. K. (2017). Driving forces of the development of adaptive behavior of personality: methodological considerations. Modern Scientist, 8, 44-47.

URL: http://b-dictionary.globala.ru/brand, 2010

URL: http://dictionary.reverso.net/english-definition/brand, 2009

URL: http://www.thefreedictionary.com/brand, 2009

Villalobos, J. V. (2018). Politics as a requirement. On the concept of Human Rights and the right to an autobiography as an ethical category. Opción, 34(85-2), 9-19.

Wierzbicka, Anna. (1991). Cross-cultural Pragmatics: The semantics of human interaction. Berlin: Mouton de Gruyter. https://doi.org/10.1515/9783112329764

Yee, S. W. (1990). Drama in Teaching English as a Second Language - A Communicative Approach. The Teacher. Retrieved from https://journals.melta.org.my/index.php/tet/article/view/479

Zare, H., \& Rajaeepur, S. (2013). The Tasks Of Social Workers Working With Children Of Divorce: A Review, UCT Journal of Management and Accounting Studies, 1(1), 5-10.

Zavershinskaya N. A. (2004). Oppozitsiya "svoego" $i$ "chuzhogo" v sovremennoi culture// Vestnik Novgorodskogo gos.universiteta, 41-47.

Abdullina, L., Gabdreeva, N., \& Ageeva, A. (2019). Using the "Flipped classroom" model in the teaching of the theoretical disciplines (French language) at the university.

Zusman V. G. (2001). Svoe i chuzhoe kak koncept culturologii/Mezhculturnaya communicatsiya. - Nizhniy Novgorod, 242-243.

\section{Copyrights}

Copyright for this article is retained by the author(s), with first publication rights granted to the journal.

This is an open-access article distributed under the terms and conditions of the Creative Commons Attribution license (http://creativecommons.org/licenses/by/4.0/). 